\title{
DIFFERING MEMBER STATE APPROACHES TO THE DEVELOPMENT OF THE \\ EU BATTLEGROUP CONCEPT: IMPLICATIONS FOR CSDP \\ Laura Chappell, University of Surrey
}

\begin{abstract}
This article will analyse the challenges facing CSDP through an evaluation of the impact that differing member state strategic cultures have on the EU Battlegroup Concept, highlighted through the examples of Germany and Poland. The concept was initiated to give the EU an increased rapid reaction capacity. However, as emphasised through the cases of Germany and Poland, divergences in EU member states' strategic cultures remain, including when, where and how force is used. When this is combined with the cost of plugging military capabilities' gaps, the political willingness to deploy a Battlegroup can be affected. Whilst the article highlights that the role that member states want to play within CSDP as well as international expectations can override constraining factors, the Battlegroups rely on a rotation system. As some member states are more willing to deploy the Battlegroups than others, the concept risks becoming a declaratory policy thus undermining CSDP.
\end{abstract}

\section{INTRODUCTION}

The Battlegroup Concept was initiated in 2004, when the EU was trying to develop its role in the global security environment following divisions over the Iraq war. Building upon the Artemis mission, the European Security Strategy (ESS) and the European Capability Action Plan (ECAP) process, it sought to provide a value-added rapid reaction mechanism for military action, within the member states' limited capabilities, whilst at the same time avoiding duplication with NATO's reaction force. However divergences among the member states regarding CSDP including when, where and how force should be used, threat 
perceptions and the role of multilateralism, encompassing Atlanticist and Europeanist visions for CSDP, also affect the Battlegroups. The concept therefore acts as a prism through which the challenges facing CSDP can be viewed.

This paper will analyse member state attitudes to the Battlegroups through a focus on two neighbouring countries, Germany and Poland. In particular, the article assesses the impact that two different strategic cultures have on the Battlegroup Concept and in turn how this affects the overall development of CSDP. These divergences encompass when force is used, threat perceptions and multilateralism. Additionally there are also divergences between Germany, Poland and the EU level, such as where force is used. The article will highlight the implications these divergences have for the functioning of the Battlegroups and how this one concept highlights the overall problems within CSDP.

Strategic culture will form the analytical foundation of the paper. It is particularly salient as it focuses on when, where and how force is used, which are central issues within the Battlegroup Concept. In particular a country's strategic culture provides its policy-makers with a range of beliefs, attitudes and norms concerning what actions are appropriate within the security and defence field. This also informs the discussion concerning the potential emergence of a European strategic culture which encompasses how far member states' strategic cultures are converging, highlighting that strategic culture can be subject to change. Indeed, both German and Polish approaches to security and defence issues have incrementally shifted, highlighting that aspects of their strategic cultures have come into conflict. This has placed pressure on both countries to play a more active role. The pressure to be more active, can also be highlighted through constraining and facilitating factors. These encompass international expectations, aspirations that the concept creates and financing. The former underlines the role that the international community expects a country to undertake and is particularly important in the German case due to the centrality of reflexive 
multilateralism in German strategic culture. Whilst the international community has pressured Germany into taking on a greater role following the end of the Cold War, this has conflicted with the country's restraints on the use of force. Aspirations to play a greater role are meanwhile particularly pertinent in the Polish case. In particular the Poles' emphasis on being involved in decisions affecting their interests has overridden the country's narrower security interests. Despite these pressures, financing acts as a constraint on what Germany and Poland can in reality achieve. Indeed the article will underline that those countries which are the most willing, such as Poland, are restricted militarily.

Whilst this article could be seen as a purely academic exercise considering that the Battlegroups have not been used, it is argued that assessing where, in which circumstances and with which partners the Battlegroups should operate has important implications for the development of the EU as a security and defence actor. Thus does involvement in a concept such as the Battlegroups encourage member states such as Germany and Poland to take up a greater role than they otherwise would? If these issues do not correspond with German or Polish perceptions on the use of force, how will this impact upon their willingness to participate? Through interviews with Polish and German security and defence elites, it is possible to highlight the extent of each country's participation in the Battlegroups and how far their strategic cultures have shifted to take account of the new security situation and their role within it. This includes such issues as deploying force outside of Europe, acting without a UN mandate, activeness regarding the use of force and views on the EU as an independent security actor, which ties in with their approaches towards multilateralism and Atlanticism.

Finally, conclusions can be drawn regarding the development of CSDP, particularly concerning the limits of member states' participation and consequently the restrictions placed on the EU's role in the international environment. In particular the article concludes that a European strategic culture must be development further in order for the EU to become an 
effective security actor. Indeed, whilst convergence between German and Polish strategic cultures has occurred, this still leads to a lowest common denominator strategic culture which is unable to provide guidance regarding military interventions abroad. This has led in part to the non-deployability of the Battlegroups and consequently has dented the EU's effectiveness as a military actor.

\section{A EUROPEAN STRATEGIC CULTURE?}

Strategic culture can be defined as the beliefs, attitudes and norms towards the use of force, held by a security community which has had a 'unique historical experience' (Gray 1999, 5152). Of particular importance, is the way in which historical experiences and memories are interpreted. As this differs from one country to the next, a strategic culture is distinctive to the society that holds it (Duffield 1998, 23; Gray 1999, 51). As historical experiences become embedded in society over a period of time, not least due to written records and commemorations, a strategic culture passes from one generation to the next making it highly stable (Longhurst 2004, 19; Wendt 1999, 163). Nonetheless, strategic culture sets the limits of the possible rather than acting as a tool by which to choose a hierarchy of choices for each set of circumstances. Therefore it shapes rather than determines a country's security and defence policy. As such it fits into Gray's premise that behaviour is an integral part of strategic culture in contrast to Johnston's opposing rationalist view which highlights the breaking of the link between attitudes and behaviour to create a version of strategic culture which is falsifiable (Johnston 1995, 35-36; Gray 1999, 55).

Whilst continuity is stressed, strategic culture is not static. Change in strategic culture usually occurs in reaction to events in the external security environment, although this does not automatically happen due to the socialisation and thus institutionalisation of strategic culture. The most profound changes usually occur in reaction to war and conflict and lead to 
the complete replacement of a society's strategic culture as occurred in the case of Germany after the end of the Second World War. This is however extremely rare and instead the advent of new security conditions as seen with the end of the Cold War in 1989 or 9/11 will usually produce more moderate, gradual change (Longhurst 2004, 20). Indeed, whilst Polish and German strategic cultures have shifted, there is agreement on the main tenets of both countries' security and defence aims across the political spectrum.

To what extent can an organisation such as the EU possess a strategic culture? Opinion is divided with Cornish and Edwards, Meyer and Reis suggesting that an EU strategic culture is beginning to emerge while Heiselberg, Rynning and Baun argue that there is not enough convergence at the EU level on the use of force to facilitate one (Baun 2005; Cornish and Edwards 2005; Heiselberg 2003; Meyer 2006; Reis 2009; Rynning 2003). Studies also differ in relation to whether they look at convergence and divergence between member states in order to ascertain if a European strategic culture is being created (Meyer 2006) or whether they focus on the EU level (Toje 2005; Rogers 2009). This article sides with Meyer as CSDP is an intergovernmental area and thus it is the member states who decide whether to create a concept such as the Battlegroups or deploy troops abroad.

However, a European strategic culture will not replace national cultures but will rather provide an additional layer. Whilst some convergence between national strategic cultures will be necessary, they do not have to be identical for a common position to occur. As Meyer $(2006,7)$ states 'it should be conceived of primarily as the increasing institutionalisation of those ideas, norms and values that are sufficiently shared at the national level'. Therefore, member states must share common views regarding when (operational scenarios), where (location of EU operations) and how (multilateralism and the rule of law) the EU as an independent security actor uses force. 
Nonetheless, once the EU member states have decided upon political documents and military concepts, it is still of relevance to compare a country's views on the use of force to these. In particular, it is one thing for a member state to sign up to a concept and another to enact it. This will also depend on whether a country has the ability (i.e. relevant military capabilities) to carry out the necessary military action, whether they are under pressure to contribute (international expectations) and how far the military action matches their own aspirations. Therefore German and Polish positions on when, where and how force should be used will be compared to the current ideas underlying the Battlegroup Concept. In addition, their military capabilities and the impact of international expectations and their own aspirations will also be covered.

\section{CASE STUDY SELECTION AND GERMAN AND POLISH STRATEGIC CULTURES}

At first sight the choice of Germany and Poland does not seem obvious. Nonetheless, it is argued that these two countries illuminate both the challenges of the Battlegroup Concept and that of the wider CSDP. Whilst the larger member states will shape the development of CSDP, it still requires agreement from a wider number of countries than the two military powers: France and the UK. In the context of an enlarged EU, this is particularly significant considering the differences in threat perception between the 'old' and 'new' member states which could impact upon when, where and how the EU uses force. In this respect a comparison between Germany, as an 'old' member state and Poland as a 'new' member state is illuminating. Although it is important to focus on larger member states as they have more opportunity to obstruct the Battlegroups due to their larger role and political clout, this dimension should also be taken into consideration. Additionally, it is important to concentrate on countries which have been under pressure to do more to participate and to take up 
leadership roles. This is due to the fact that these types of countries are more likely to have a greater impact on the developing capabilities that CSDP and consequently the Battlegroups have at their disposal, than those countries which are already doing enough and are therefore not increasing their contributions. Evidently Germany and Poland fall into this former category. Indeed, many of the Battlegroups do not encompass either France or the UK. In other words, due to the rotating nature of the Battlegroups, it is essential that all member states have the ability and willingness to deploy. The concept also allows medium sized member states to come forward and take up a leadership role.

In consideration of the above, this article looks at two larger member states which are playing leading military roles as Framework Nations in the EU Battlegroup Concept. As the largest and most vocal new member state with an increasing role within CSDP and a Framework Nation for three Battlegroups, Poland is the obvious choice. Germany meanwhile co-introduced the Concept at the EU level and is one of the largest contributors. Germany and Poland represent 'more different' cases in this article, in particular Poland's recent membership of the EU in comparison to Germany's original membership status, their differing views on when force is used and multilateralism as well as their economic size. Despite these differences, both Germany and Poland could have problems with the Battlegroups due to the challenges that the concept creates for their individual strategic cultures in addition to the potential lack of military capabilities.

Germany's strategic culture is historically represented by the concept of 'Stunde Null', which led to a feeling of 'never again' (Longhurst 2004, 46). This concept led to two further sentiments which came together to form the core of Germany's strategic culture. First was the rejection of nationalism, which led to the country's reflexive multilateralism. Second was the culture of restraint on the use of military force (Duffield 1994, 179). In relation to the former, reflexive multilateralism relates specifically to the integration of the country into western 
security structures such as the EEC and NATO and placed an emphasis on working with partners and in coalitions by consensus. Additionally it encompasses Germany's sowohl als auch policy of not choosing between its EU and NATO partners. Connected to this is an emphasis on working within multilateral frameworks and within international law, in addition to demonstrating reliability and predictability in foreign policy.

This key element has however placed pressure on the country's restrictions concerning the use of force. After the end of the Cold War the country's allies asked that Germany 'normalise' its role in foreign affairs rather than continuing to engage in checkbook diplomacy. This has meant that a conflict has occurred between the country's reflexive multilateralism and its culture of restraint on the use of force, which has resulted in a widening of the latter following in particular the massacre at Srebrenica. What has occurred since is an incremental shift in the country's strategic culture towards deploying German forces out of area for humanitarian reasons.

Meanwhile Poland's strategic culture has been formed through its experience of heroic defeat and victim of Realpolitik, as evidenced at Yalta when Poland was deserted by its allies and placed under the Russian sphere of influence (Osica 2004a, 304-305). Thus at the core of the country's strategic culture is the protection of Poland's independence. This has led to the country's instinctive Atlanticism as only the US through NATO's Article Five could protect the Poles' security, a proclivity to use force, being a reliable ally as well as an emphasis on 'nothing about us without us'. This last point encompasses a central and vocal role in European decision-making. Additionally the Poles are sceptical of multilateral institutions, which relates to the UN rather than the EU and NATO both of which were seen as the country's 'return to Europe'. Essentially the Poles are sceptical about the effective functioning of an organization which includes differing values within the Security Council (i.e. Russia) (Osica 2004b, 14). 
As in the German case, Polish strategic culture has also seen incremental change. In particular, in order to be seen as a reliable ally and to be included in decisions affecting their interests, Polish policy-makers have had to widen their regional approach to security and commit to sending troops further afield, as seen in EUFOR RD Congo and EUFOR CHAD/RCA. Additionally, the Poles also see this as a way to increase their influence in CSDP and as a political commitment.

Poland and Germany represent differing views on some of the major issues concerning CSDP. Whilst Germany's culture of restraint conditions the Germans' strict parameters for the deployment of the Bundeswehr, which is reflected in the decision-making process, the Poles have a pro-active view on deploying force. However, the Poles' proAtlanticist orientation shapes its views concerning the tasks that CSDP should undertake, which also impacts on the Battlegroups. This is in slight contrast to Germany's sowohl als auch policy. Finally Germany is a reflexive multilateralist and as such working with partners within the strict parameters of international law is essential. Poland meanwhile is sceptical regarding multilateralism, which impacts upon such issues as the necessity of a UN mandate.

The two countries do however share a more regional view on where force could be used which has the potential to conflict with the Battlegroup Concept as the EU has a global security focus. For Germany, this relates to restrictions on the use of force and for Poland to their emphasis on the country's independence which highlights threats closer to home. Thus, questions have to be asked concerning the likelihood of the Battlegroups acting within the new member states' sphere of interest and how this is impacting upon declared commitments.

\section{INTRODUCING THE EU BATTLEGROUP CONCEPT}

The EU Battlegroup Concept was initiated at a joint Anglo-Franco summit at Le Touquet in February 2003 and fleshed out at a further joint summit in November 2003, following the 
successful completion of the Artemis operation to the Congo. However, it was officially submitted as a UK, French and German initiative to the Political and Security Committee (PSC) on 10 February 2004, after the then German Minister of Defence, Dr Peter Struck, expressed interest in the idea in informal talks at the Security conference in Munich. The concept was finalised at the military capability commitments conference on 22 November 2004 and included in the Headline Goal 2010.

The Battlegroup Concept aims on giving the EU a highly mobile set of forces, which are capable of rapid deployment. They are considered to be 'the minimum militarily effective, credible, rapidly deployable, coherent force package capable of stand-alone operations' (Council of the European Union 2007, 2). Each Battlegroup consists of 1500 armed forces personnel, should be sustainable for at least 30 days, although it can be extended up to a maximum of 120 days and can be formed either unilaterally or multinationally. The exact composition of each Battlegroup is however up to the contributing member states. Nonetheless as Lindstrom $(2007,15)$ outlines 'a 'standard' EU BG is likely to include a headquarters company, three infantry companies, and corresponding personnel', which 'may include mechanised infantry, combat support elements and combat service support elements'. The decision to launch an operation should be taken five days after the agreement by the Council and the operation should be deployed ten days after the decision by the EU. From 2005 until $1^{\text {st }}$ January 2007, the Battlegroup Concept was at initial operating capacity whereby only one Battlegroup was on standby at any one time. As of January 2007, the Battlegroups are at full operational capacity whereby two Battlegroups will be on standby and rotated every six months. Table 1 shows all the Battlegroups that have been committed by the member states from 2005 until 2015.

The Battlegroup Concept is built upon three core activities: the Helsinki Process including ECAP, the successful Artemis mission to the Congo in 2003 and the ESS. ECAP 
was launched so as to close the EU's military capabilities' gaps. Thus not only has the Battlegroup Concept filled a shortfall but it has also arranged a way in which troops and resources can be used and on call during specific periods. The Artemis Mission was utilised as a template to flesh out how the Battlegroups would work. Artemis involved the deployment of around 1800 primarily French troops, to Bunia in order to contribute to the stabilisation of security conditions and improve the humanitarian situation (Koivula 2005, 16). Finally the ESS outlines the stance taken by the member states concerning inter alia threat perceptions, multilateralism and increasing capabilities. Thus it represents the political foundations of the Battlegroups as the concept will be based on this broad agreement.

(Insert Table 1 here)

\section{OPERATIONAL SCENARIOS}

When should force be used? The EU is divided between those member states who have strict criteria on the use of force such as Germany and others who have a more pro-active approach which includes Poland. Germany's culture of restraint has ensured that their focus is placed on a comprehensive approach to security encompassing primarily civilian aspects. In contrast Poland's pro-active view on the use of force is based on a belief that the Poles should support their allies. However, this stance has to be tempered by the Poles' 'instinctive Atlanticism' (Longhurst and Zaborowski 2003, 1010). Similar to many of the Central and East European Countries the Poles rely on NATO's article five guarantee, underwritten by the Americans, for their security. Hence, it is essential that CSDP and NATO complement rather than conflict with one another.

What tasks are the Battlegroups likely to undertake? The General Affairs and External Relations Council stated that the spectrum of crisis management operations covered by the 
Treaty on the European Union 'includes humanitarian and rescue tasks, peace-keeping tasks and tasks of combat forces in crisis management, including peacemaking. As indicated by the ESS, this might also include joint disarmament operations, support for third countries in combating terrorism and security sector reform' (Council of the European Union 2004, 7). Clearly, the Petersberg Tasks in addition to new tasks as outlined in the ESS form the core missions for the Battlegroups. However, the missions have to be limited in scope as the Battlegroups can only be used for a short period of time and due to their size, only in certain situations. Indeed, this was the EU's reasoning behind the rejection of the use of the Battlegroups in Congo in 2006 and Chad in 2008 (Chappell 2009). Therefore, the Battlegroups are to be used as an initial entry force, if necessary to be followed by a larger force either from the EU itself or another multilateral body such as the UN or NATO. As Andersen $(2006,25)$ emphasises, the Battlegroups 'are driven by the underlying principle, "first force in, first force out" in humanitarian assistance missions and military crisis management tasks'. Alternatively they can be used as a bridging force to allow another organization e.g. the UN to regroup their forces or to refocus the mission.

From the above, the types of missions the Battlegroups will undertake do not represent an insurmountable political obstacle to either Germany or Poland. First, the most likely tasks the Battlegroups will perform will initially not be too high in intensity. As Kerttunen $(2005$, 36) highlights 'separation of belligerent parties by force is far too demanding'. From a German viewpoint they can only be used up to and including nonpermissive environments, whereby there might be some resistance from small rebel groups. ${ }^{1}$ So, for those countries which have restrictions on the use of force such as Germany, participating in the Battlegroups appears feasible. Additionally these tasks do not conflict with the defence policies of Atlanticist countries such as Poland, which does not wish CSDP to encroach on article five tasks. 
Both German and Polish decision-makers are keen to stress that CSDP's added value lies in its holistic approach to security matters encompassing civil-military tasks. The former Polish Minister of Foreign Affairs Rotfeld has highlighted the possible usage of the Battlegroups in humanitarian interventions, concurring with Andersen's point above. $\mathrm{He}$ stated that, 'the European Union is establishing battle groups. The humanitarian disaster in South-East Asia points to the need for remodelling the concept of such groups, so that they will be able to deliver effective international relief in such crisis situations.' (Rotfeld 2005, 16). It is interesting that Rotfeld highlights remodelling the Battlegroup Concept in order so that they take on softer security tasks, which indicates the country's preference for the EU to concentrate more on the civilian side so that it avoids conflicting with NATO's security role. A similar view has also been articulated by the chairman of the EU Military Committee, French General Henri Bentegeat who is reported to have suggested that the Battlegroups should be used primarily for natural disasters (Czech News Agency 2009).

Whilst the views of German and Polish policy-makers highlight a common approach regarding potential missions, the question remains as to whether the Battlegroups will end up carrying out operations at the lower end of the Petersberg Tasks due to member states' restrictions regarding the use of force. Finding a consensus has already impacted upon what missions the EU is prepared to undertake within the CSDP framework. Considering the focus of Germany in particular, is on softer security aspects, the Battlegroups highlight that the same restrictions apply.

\section{WORKING WITH THE UN AND NATO}

From the tasks listed above, clearly the Battlegroups could work with other international organisations, in particular the UN and possibly NATO, reflecting the centrality of 'effective multilateralism' in the ESS. However Germany and Poland represent different perspectives 
concerning multilateralism. Reflexive multilateralism is one of the keystones of Germany's security and defence policy. Thus working with partners and international institutions in addition to only deploying force in a multilateral context, is of central importance to German policy-makers. In contrast, Poland is more sceptical of multilateral institutions with the exception of the EU in relation to non-military issues and NATO. Nonetheless Polish policymakers signed up to the ESS and their stance towards the UN has become more pragmatic.

Although the Battlegroups are designed to work independently of organisations such as NATO, working with other multilateral institutions is envisaged depending on the tasks that the Battlegroups will carry out. Two issues stand out in regards to CSDP-UN cooperation. The first relates to how the Battlegroups would fit into an overall strategic framework in missions whereby the Battlegroups form one part of the mission. In relation to EU-UN cooperation involving the Battlegroups two scenarios can be envisaged: bridging operations by EU forces and the stand by model which would encompass an EU 'over the horizon reserve' or an 'extraction force' to support UN operations (European Council 2004, 3-5). However the Battlegroups would then be contributing to UN missions, which highlights issues related to operational command (Gowan 2005, 16). Moreover, the EU could undertake missions independently with a UN mandate. Indeed, it does not necessarily have to be the UN who backs up or initiates the request for the Battlegroups. The EU could arguably work with other organisations such as NATO or respond to crises at the request of a nation state's government. The same applies to the extension or take-over of a mission. Whilst this task has been connected with the UN, it is possible that NATO could fulfil this task too.

Despite the differing importance of multilateralism in German and Polish foreign policy, working with the UN is seen by both as being worthwhile. Although German policymakers' ensured that the Battlegroup Concept was re-focused away from being used primarily by the UN, they still see the organisation as central to international security. As the 
German Minister of State Erler $(2007,2)$ emphasises, 'the EU is currently studying the lessons learned from its Congo operation (...). These lessons are also of value to the EU Battlegroups (...) which can support above all the UN in crisis management'. From a Polish standpoint, whilst the country's security is not so centred on multilateralism and the UN, it does still see the importance of the EU working with the UN, particularly considering that both organisations do possess some similarity of role in regards to crisis management and civilian engagement. However the UN is seen within the spectrum of international organisations, all of which have a role to play in international security. ${ }^{2}$

The second issue relates to the necessity of a UN mandate as this is not specified in the Battlegroup Concept. Therefore, from the standpoint of the member states, is a UN mandate an absolute requirement for a Battlegroup mission? Again divisions occur between those member states who believe a UN mandate is essential and those who highlight time delays in addition to the potential subjugation of EU security and defence issues to non EU countries who are represented in the Security Council (Lindstrom 2007, 52). For the Poles, a UN mandate is not compulsory for action although as far as possible one should be obtained. Thus Poland's decision-makers would be prepared to act without one, particularly if there is a responsibility to protect. ${ }^{3}$ Evidently in Germany, there are stricter criteria on when using force is permitted. Thus a UN mandate is almost a pre-requisite for action although there exists a very small possibility to act in the absence of one or at least to act in a wider interpretation of a mandate. ${ }^{4}$ However this refers to the evacuation of German citizens rather than for military action. Clearly, a UN mandate should be seen as a pre-requisite for ensuring action particularly due to the lack of time that the Bundestag would have to discuss and approve the deployment of a Battlegroup.

Considering the number of Atlanticist countries within the EU, CSDP-NATO compatibility is essential. As the then Polish Prime Minister, Meller $(2006,7)$ stated, 'we will 
support the process of elaboration of the European Policy of Security and Defense, so as to make it complementary to the capabilities and resources of NATO. This applies, in particular, to the collaboration of NATO's Response Force and the Union's Battle Groups'. Essentially, Polish, in addition to German, decision-makers work from the assumption that they have one single set of forces and procedures. These should be developed to use in both the Battlegroups and the NATO Response Force (NRF) as neither country can afford different types of equipment or training standards in the context of static or declining defence budgets. As Lindstrom $(2007,25)$ underlines 'planners recommend that EU BG contributors rely on already existing NATO standards and criteria to encourage interoperability and avoid duplication'. In a broader context, this relates also to all missions undertaken within CSDP and NATO frameworks. Additionally both German and Polish policy-makers realise that the Battlegroups cannot rely upon NATO assets. This is not only for political reasons but also due to the short timeframe available in which to deploy a Battlegroup.

Despite differences between Europeanists and Atlanticists concerning how far EU and NATO should work together, this is not an issue in the Battlegroup Concept. First financing plays an intervening role in ensuring the centrality of CSDP-NATO compatibility. Second, Atlanticist countries such as Poland have accepted that CSDP can act independently of NATO as long as it does not unnecessarily duplicate equipment and tasks.

\section{THE LOCATION OF BATTLEGROUP OPERATIONS}

Where should CSDP operations more broadly and the Battlegroups specifically operate? The ESS encompasses a global focus which is also reflected in the report on its implementation. Whilst there is no kind of operational range for the Battlegroups in the Headline Goal 2010, there is a $6000 \mathrm{~km}$ from Brussels planning assumption. The Memorandum of Understanding (MoU) for the Polish led Battlegroup states that the Battlegroup 'will take part in operations 
anywhere outside the EU with a planning assumption of $6000 \mathrm{~km}$ from Brussels or as otherwise defined in relevant EU BG documents' (Memorandum of Understanding 2006, 9). Therefore $6,000 \mathrm{~km}$ is not seen as the ultimate limit of the Battlegroups' reach in the long term.

To what extent do member states' defence interests extend beyond Europe? Whilst there has been convergence between the member states concerning the EU's role in the world, differences still exist regarding security interests and activism in military affairs. Looking at Poland and Germany, both countries' policy-makers have a more regional focus for their security interests. Polish security fears tend to be focused on Russia, whilst Germany's decision-makers are still wary when using force 'out of area' and so missions need to have a humanitarian element. Additionally, many of the new member states will form the EU's border for a considerable time and therefore regional security is of utmost importance. This is combined with a continued suspicion over Russian intentions in the region (138 ${ }^{\text {th }}$ Bergedorf Round Table 2007, 27).

Whilst for both German and Polish decision-makers, missions on the European continent are clearly in their country's security interests, this is not so obvious in Africa. Indeed, Germany's security and defence elites were originally concerned that the Battlegroup Concept would only be used in Africa. At the same time, the value of the concept was understood and they therefore refocused the concept so that it could be used for all crises and conflicts. ${ }^{5}$ This reflects German concerns that other member states are using CSDP as a way of sharing their colonial responsibilities both financially and politically. ${ }^{6}$

These German concerns can clearly be highlighted in the debate concerning the country's participation in EUFOR RD Congo. Menon highlights that, 'during discussions of the deployment to the DRC in 2006, German officials voiced their fear of being 'instrumentalized' by their French and Belgian colleagues' (Menon 2009, 240-241). This was 
underlined by the fact that the request came from Guéhenno, the head of the UN peacekeeping department and a French diplomat and circumvented normal procedures, leading to German concerns that this was a French rather than a UN request (Gross 2009, 150; Alecu de Flers, Chappell and Müller 2011, 16). Indeed some policy makers as well as the public find it difficult to understand why the Bundeswehr should go to Africa, which cuts across party lines. ${ }^{7}$ This is also a reflection on the Germans' restrictions on the use of force. Therefore, as Ryjáceek (2009, 495) states 'the government found itself with two dilemmas: first between the positions in favour and against; and second between domestic constraints and international commitments'.

Initially the use of a Battlegroup had been suggested by the French. However, as the Germans would be left to pay for the majority of the mission due to the "costs lie where they fall" principle in addition to issues such as it was not a rapid reaction operation and the Battlegroup in any case could not fulfil the mission remit, the Germans declined (Alecu de Flers, Chappell, Müller 2011, 16-17). Nonetheless, in the end the Germans' effective multilateralism pushed the boundaries of its restraints on the use of force and the country, under pressure from France, became the Framework Nation for the EU mission which was eventually sent. Therefore as Alecu de Flers, Chappell and Müller (2011, 18) state 'German leadership in EUFOR RD Congo can be seen as Germany taking its turn to ensure the ongoing development of the ESDP and to support attached concepts such as 'effective multilateralism' rather than an increasing interest in Africa'. This is highlighted by the fact that Germany only contributed four officers to the OHQ in the next African mission, EUFOR RD Chad/RCA.

For its part, Poland's policy-makers wish the country to play the role of 'a good European', showing solidarity to other European countries which do have interests in the region. Polish decision-makers also saw participating in missions outside their security 
interests as a political investment as CSDP could be needed for possible contingencies and so there is a need to build a link for reciprocity. ${ }^{8}$ However the EU's concentration on SubSaharan Africa for CSDP missions has also led to the Polish Undersecretary of State for Defence Policy Komorowski calling for CSDP to be made 'more geographically balanced' (Komorowski 2008, 4). Thus the Poles want to ensure that the EU does not forget about other regions closer to home. This is because the security situation in Eastern Europe directly impacts on the Polish security situation and reflects Polish threat perceptions which are concentrated on the neighbourhood.

Nonetheless, the Poles have continued to support and contribute to the EU Battlegroup Concept for a couple of reasons which link to the country's strategic culture. First Poland's emphasis on nothing about us without us has involved a willingness to be actively involved in the Battlegroups. In particular, Polish policy-makers expect that if the country is active in regions incorporating other countries' security interests then they are more likely to reciprocate when a problem occurs in Eastern Europe (Alecu de Flers, Chappell, Müller 2011, 19). In this respect, Polish policy-makers can have a greater influence on the development of CSDP if they actively participate in it. Second Polish policy-makers wanted to prove the country's predictability in security and defence matters, particular in contrast to its unpredictability in other areas of the EU, which occurred under the Kaczyński leadership. These two aspects have overridden the Poles' regional security approach which is based on the country's threat perceptions.

Evidently, there is a division between member states such as Germany and Poland, who would prefer CSDP to operate primarily in Europe and Eurasia and the broad security interests of the EU as set out in the ESS. Indeed it should be noted that Germany, along with the UK, once again rejected a Battlegroup deployment to the Eastern Congo at the end of 2008. One of the reasons behind this was the reluctance to engage troops in Africa, mirroring 
German concerns in 2006 as highlighted above (Menon 2009, 236). Thus such divisions which can be seen within CSDP in general, clearly have implications for the Battlegroups.

\section{FINANCING DEPLOYMENT}

Whilst political issues often take centre stage when deciding on a mission, intervening factors must not be forgotten. Financing in particular can act as a constraint to action. In the Battlegroup Concept this relates specifically to getting the Battlegroup to the theatre of operations, primarily through strategic airlift due to the strict deployment timeline. The French, German, British 'food for thought' paper states that 'member states offering BGs will need to ensure that their bid includes appropriate strategic lift assets, pre-identified, earmarked and available to meet the 15-day target' (France, Germany, UK 2004, 3). In relation to strategic lift, 'up to $200 \mathrm{C} 130 / 30 \mathrm{C} 17$ (outsized) aircraft sorties for initial deployment to a central African theatre' would be required (France, Germany, UK 2004, 4).

The EU as a whole suffers from a lack of strategic airlift, which is essential if the Battlegroups are to be deployed in the time allotted. Poland has acquired six C-130s as part of the financial package for the F-16s, the first of which arrived last year. This will improve Poland's strategic airlift capability although evidently it falls far short of what is required to deploy a Battlegroup. A number of member states, including Germany have ordered the A400M which has been beset with problems. It is so severely delayed that the German Federal Ministry of Defence even considered whether to cancel its order (Spiegel Online 2009). ${ }^{9}$ However, the A400M does not necessarily plug the EU's strategic airlift gap as it only holds 29 metric tons. Andersson suggests that to deploy a Battlegroup with 30 days of supplies 'would require the transportation of around 150 standard size containers of equipment and stores with a combined weight of somewhere between 1,500 and 3,600 metric tons' depending on whether water is included or not (Andersson 2006, 29; See also Kerttunen 2005). Nonetheless, the conditions on the ground also have to be taken into consideration. 
This includes whether there is a runway long enough to land large transport planes, near to the location of the operation. In this respect the A400M is useful as it needs a shorter runway than air transport planes such as the AN-124 and the C-17 (see Lindstrom 2007, 34).

Additionally the creation of a European Air Transport Fleet, which Germany is participating in, has been announced. This will concentrate on pooling aircraft such as the A400M and the C-130, although the effectiveness of such a fleet without the pool of A400Ms has to be questioned. Another option is to use the Strategic Airlift Interim Solution (SALIS), in which Ukrainian AN-124-100 Condor planes are rented out for a set number of hours. A number of EU countries are part of this initiative including Poland and Germany. Finally Poland is participating in the Multinational Strategic Airlift Capability which has been developed by NATO in which $3 \mathrm{C}-17 \mathrm{~s}$ have been jointly purchased. The $\mathrm{C}-17 \mathrm{~s}$ are based at Papa Airbase in Hungary and have thus far been used to support ISAF and the Kosovo mission in addition to providing humanitarian relief in Haiti (NATO 2010). ${ }^{10}$ In addition to NATO missions, the C-17s could be used for UN or EU operations.

There are two problems with these types of initiatives. First is the question as to whether the flying hours and the planes themselves will be available when required for a Battlegroup mission. Second is the cost of actually leasing aircraft. As Menon (2009, 239) states 'the cost to the UK Exchequer of leasing four C-17s from Boeing has been put at $\$ 200,000$ per aircraft, whilst that of a single Antonov flight to Afghanistan as part of ISAF is around \$250,000' (see also Lindstrom 2007, 35; Jacoby and Jones 2008, 337). The costs put leasing arrangements beyond many member states.

In consideration of the costs involved, will the member states be prepared to participate and/or pay for a mission? Currently missions are funded through 'common costs' and through the 'costs lie where they fall' principle, which are borne directly by the member states. The former are funded through the Athena mechanism and member states contribute to 
this depending on their gross national income. Hence Germany, which funds $20.97 \%$ of the common costs, is the largest contributor, whilst Poland, which puts in $2.21 \%$, is tenth (EU Council Secretariat 2006, 5). Another issue concerns Battlegroup transport costs as these were previously considered as common costs (Menon 2009, 239). Thus for poorer member states such as Poland this made participating in the Battlegroup Concept financially easier as

the burden of strategic transport was lessened. ${ }^{11}$ The question was therefore whether those countries which pay a higher share of the common costs and are not participating in a Battlegroup mission would be prepared to use the Battlegroups as opposed to ad hoc arrangements. Nonetheless, in relation to the potential use of the Nordic Battlegroup for the Chad mission in 2008, Jacoby and Jones $(2008,332)$ underline that 'the Swedish political leadership may have quietly signalled that they could not afford a deployment. As the lead nation, and without a common EU budget to tap, the huge costs of deployment to Chad 'lay where they fall', which was to say on Sweden'. If Sweden could not afford to deploy the Nordic Battlegroup under this arrangement it is difficult to see how poor member states such as Poland will be able to deploy under the new rules in which transport costs are no longer seen as common. In this sense the actual conundrum is that those member states that are willing to deploy are in fact financially unable to do so.

\section{DECLARED COMMITMENTS}

Considering the divergences among the member states concerning where and when a Battlegroup should be used, how has this impacted upon their declared commitments to the concept? From Table 1, it appears that the member states are committed to the concept. 25 out of 27 member states in addition to possibly five non-EU countries are participating and all slots up until the first half of 2012 have been filled. By far the largest contributors are Germany and France who are participating in nine and ten Battlegroups respectively. 
Interestingly 11 and possibly 12 member states have also agreed to be Framework Nation (FN) for the Battlegroups, highlighting the concept's usefulness in expanding the number of countries who are willing and capable of undertaking a leadership role beyond the large member states.

This is assisted by the fact that Battlegroups can be formed multinationally. Therefore for a country such as Poland becoming an FN for a multinational Battlegroup represents a compromise between two extremes: to form their own Battlegroup or to join another FN. However as Kawałowski underlines the creation of a national Battlegroup 'will be worth considering in the future as it will follow the transformation process of the Polish military forces, the implementation of conclusions of strategic defence reports, as well as operational experience (Iraq, Afghanistan, DR Congo)' (Kawałowski 2007, 53-54). ${ }^{12}$ Clearly though, Polish transformation is occurring whilst working in conjunction with other countries in the Battlegroup concept in addition to NATO as this enables the Polish armed forces to identify 'capability areas that need to be developed. These include for instance CIS, NBC, ISTAR and strategic lift' (Gągor 2007, 2). Indeed Polish officials see cooperation between countries as positive in respect to the Battlegroups. ${ }^{13}$

Meanwhile, for German policy-makers, the country is holding up the flag of multinationalism, particularly by working with small countries and assisting Poland in its Framework Nation role. Essentially German decision-makers have made sure that those small countries that want to take part can do. Originally they worked on a $2+1$ principle whereby a Battlegroup would be made up of two large member states and one small one. ${ }^{14}$ Evidently this criterion has widened, considering that Germany is taking part in Battlegroups comprising of five countries. This highlights the centrality of multilateralism in German strategic culture, reflected by the fact that the country will not deploy force unilaterally, even if operating within a multinational organisation such as the EU. Whilst the Battlegroup 
Concept might challenge certain aspects of Germany's security and defence policy, particularly the constraints on the use of force, it allows the Germans to fulfil other central features, not least working with partners. This highlights the conflict that is taking place within German foreign policy between the Germans' strict definition on the use of force and the importance of their reflexive multilateralism.

To demonstrate how the Battlegroups encompass multilateralism as well as assisting countries to participate or act as leader, the Polish led Battlegroup in 2010 presents an interesting case as other participating countries will act as 'lead nation' for certain elements of it. Poland, as the FN are contributing 50\% of the Battlegroup, including about 750 troops and 'a core element based on a motorised infantry battalion with necessary organic combat and combat service support elements. The FN will also provide the core of the (F)HQ and a command support unit to this HQ' (Memorandum of Understanding 2006, 11; The Warsaw Voice 2006). In preparation for the standby period, Poland's $1^{\text {st }}$ Motorised Battalion in Miedzyrzecze received combat readiness evaluation of Land HQs and Units (CREVAL) certification in December 2008 (The Ministry of National Defence of the Republic of Poland 2008). Interestingly, this Battalion has had operational experience in both Iraq and Afghanistan (Terlikowski 2010, 1). Other tasks that the Poles have undertaken, include establishing the (F)HQ and providing the Force Commander, co-ordinating the training and preparation of the Battlegroup and chairing the manning conference to agree upon the manning and organisational structure of the (F)HQ and the (BG) HQ staff (Memorandum of Understanding 2006, 11-16).

Germany meanwhile is providing about $30 \%$ of the Battlegroup strength, comprising around 500 troops and is acting as 'lead nation' for logistic support coordinating this for both the Battlegroup and the Force HQ. Moreover, the country is taking the lead in terms of medical support and commanding the Multinational Medical Task Force, which the Germans 
and Poles will establish (Memorandum of Understanding 2006, 13-15). The Battlegroup is also utilising the German OHQ at Potsdam as Poland does not possess one. Slovakia is supplying 200 troops and is taking on the role of 'lead nation' for the supply of engineering resources (Memorandum of Understanding 2006, 14). Lithuania is contributing 200 personnel including, infantrymen, logistics, medicine and military police elements in addition to possibly providing some transportation, through flying hours it plans to buy using the $\mathrm{C}-17$ initiative (Baltic News Service 2006). Finally Latvia is providing 60 troops (Ministry of Foreign Affairs of the Republic of Latvia 2006). Thus there is a division of labour concerning what each country is providing, with Poland contributing half the troops necessary and Germany backing Poland up with logistic support.

\section{CREATING ASPIRATIONS AND EXPECTATIONS}

Clearly, the Battlegroup Concept has the potential to be a driver for capability development and for making the armed forces of member states more capable of undertaking rapid long-range deployments (Williams 2006, 2). Thus the Battlegroups create and/or fulfil expectations and ambitions which can override more narrowly conceived security and defence policies. As Jacoby and Jones $(2008,333)$ underline in the case of Sweden, 'the EU BG concepts gave specific shape and form to an important national ambition'. Additionally the Battlegroups are partly based on permanent structured cooperation, which politically pressurises the member states therefore acting as a catalyst for further cooperation. ${ }^{15}$ Whilst participation is voluntary, peer pressure compels member states to want to be included rather than to be left on the sidelines. This raises the question as to how far a country's threat perceptions, views on the use of force and financial considerations act as a constraint on their participation.

For the Poles, the importance of being able to participate in decisions affecting their interests in security matters means that Polish policy-makers are looking to play a key role in 
CSDP. This has spilt over into the Battlegroup Concept as the Poles' wish to take on a proactive role whilst also improving the country's capabilities. Due to Poland's policy-makers' work towards the country's NRF contribution, becoming a FN for the Polish, German, Latvian, Lithuanian and Slovak Battlegroup did not pose too many problems as the structure, units and procedures are similar, although the Battlegroup Concept 'also stimulates the development and modernisation of Polish armed forces' (Kawałowski 2007, 54). ${ }^{16}$ This can be seen with a number of military development issues which have arisen in Poland in regards to the potential Visegrad Four (Poland, Czech Republic, Slovakia and Hungary) + Ukraine Battlegroup. Whilst Poland has been invited to be the FN for the group, the country's decision-makers will have to think about operational command and whether there are enough transport capabilities, including strategic airlift, in order to go ahead. Another issue is whether Poland should acquire an EU rapid reaction OHQ.

How far the Battlegroup Concept creates aspirations and subsequently change depends on the extent to which the concept fits with the country's overall perceived role within CSDP, a point which Jacoby and Jones $(2008,325)$ have highlighted in the case of Sweden. For a country such as Poland who wishes to be seen as a constructive, active participant, the Battlegroups provide an important platform. This highlights the importance of a country's strategic culture which is instrumental in shaping what role a country should play on the international stage.

Additionally international expectations have to be taken into consideration. In Germany's case this is particularly pertinent considering the emphasis that the Germans place on multilateralism. Clearly German policy-makers have looked to shape the Battlegroup Concept politically which coincides with their traditional motor role within the EU. However they have also come under pressure from their partners to assume a greater role militarily. Thus the Battlegroups are a useful tool which allows the Germans to declare a greater 
military responsibility. This is reflected not only in the number of Battlegroups that Germany is participating in but also in their role as FN. Thus intervening factors such as international expectations and the role the Battlegroups play in promoting military development need to be taken into consideration when assessing the potential impact of divergences between the member states regarding the Battlegroup Concept.

\section{POLITICAL WILLINGNESS}

Despite the declared political and military commitment to the Battlegroups they have yet to be deployed. Therefore, are the member states actually prepared to deploy their Battlegroups wherever in the world they are needed? Whilst divergences between member states on key issues such as threat perceptions and where and when force is used has not necessarily impacted upon declared commitments, some member states appear reluctant to use the Battlegroups. The most obvious example of this concerns the use of a Battlegroup in eastern Congo to support the UN which came up for discussion in the second half of 2008. UN Secretary General Ban Ki-moon had requested a temporary EU bridging mission and the French had subsequently suggested the use of the Battlegroups. However as previously stated, this proposal was rejected by the UK and Germany both of whom were acting as Framework Nations for the two Battlegroups on standby at the time. As Menon $(2009,236)$ states in the case of Germany, 'opposition to intervention stemmed from a reluctance to send troops to Africa, coupled with growing suspicions that German troops were being used as 'cover' by certain partners to legitimize intervention in their former colonies'. Thus German concerns seem to be focused on where force is used which reflects their restrictions on the use of force and connected to this, the necessity of getting two thirds of the Bundestag to agree to any deployment. 
For other countries, such as Poland it is clear that the political willingness does exist as other domestic factors override threat perceptions and where force should be used in an EU context. Indeed, Witney has described Poland as 'a "go to" player in European defence always ready to contribute, whether to a new operation or a new collaboration (...) its determination to achieve front-rank status in defence is palpable' (Witney 2008, 24). Polish decision-makers' emphasis on 'nothing about us without us' has guaranteed Polish participation in CSDP missions and projects so as to ensure that their opinions are taken into account. Thus despite having no immediate defence interests in Africa, the Poles contributed 150 armed forces personnel to EUFOR Congo and 400 personnel to EUFOR TCHAD/RCA making the country the third and joint second largest contributor respectively. Although the Poles want to ensure that CSDP is also active in eastern Europe, as previously stated, this has not prevented them from being active in other parts of the world.

Further evidence of German and Polish policy-makers' willingness to use the Battlegroups can be highlighted through their opinions concerning the alteration of the concept to make it more usable. This came up for discussion in the latter half of 2009, when the Swedish Presidency placed the issue of the Battlegroups' usability onto the agenda. In particular, they proposed that the concept should be more flexible. Thus a Battlegroup or parts of a Battlegroup could be borrowed for operations such as EUFOR Chad/RCA. Evidently it would be up to the contributing countries of each Battlegroup to decide whether to allow their Battlegroup to be used in this way. German and Polish decision-makers have opposing views on this (Chappell 2009). The Germans have agreed not 'to block the initiatives of those who hope to allocate their Battlegroups to purposes other than those set out in the current concept' (Agence Europe 2009) which implies that they do not want to see the Battlegroups used for tasks other than rapid reaction operations. Meanwhile the Poles support the idea of making the Battlegroups more usable. As Terlikowski $(2010,2)$ highlights 
'during its own presidency, Poland should consider initiating work on an overall improvement of the mechanisms to generate military forces for CSDP missions, including the rationalization of the battle groups system'.

\section{CONCLUSION}

This article has evaluated how two different member states' strategic cultures have impacted upon their perceptions of and commitment to the EU Battlegroup Concept. In particular, two major dividing lines in CSDP have been identified: the use of force, encompassing a country's threat perceptions and atlanticism vs. europeanism. German and Polish perceptions of these key factors have then been used to assess the extent to which they impact upon the EU Battlegroups. This has therefore enabled an in-depth analysis into where conflict between German and Polish strategic cultures and the Battlegroup Concept lie and to what extent these can be overcome.

In summary, divisions between europeanists and atlanticists have not impacted upon the concept. This is due to the fact that even strong atlanticists such as the Poles realise that the Battlegroups are qualitatively and quantitatively different from the NRF and that the EU should be able to play an independent although complementary role to NATO, focusing on civil-military aspects, which the Germans also concur with due to their restrictions on the use of force. This highlights that there is an increasing convergence between the member states concerning the fact that the EU should be able to play an independent role, within the context of international law, using the full range of capabilities up to and including military force. Meanwhile the conflict between the Germans' culture of restraint and its effective multilateralism has meant that the country has widened the boundaries concerning when force can be used. Finally, both countries are restricted financially and thus compatibility between EU and NATO standards is essential. 
However the divergences which remain should not be underplayed. Member states' threat perceptions which impact upon where force should be used combined with the financial cost of deploying the Battlegroups affects the effectiveness of the Battlegroup Concept. Although the concept allows a country such as Germany to back up their political leadership role with concrete military commitment whilst at the same time demonstrating the country's multilateral credentials, the willingness to deploy has been missing. In other words, whilst international expectations have placed pressure on the Germans' restrictions on the use of force, due to the centrality of multilateralism in the country's strategic culture, this has only caused an incremental shift concerning when and where Germany uses force. Therefore, whilst German policy-makers will take their turn to deploy the Bundeswehr in CSDP operations in Africa, this has not resulted in increasing enthusiasm to send troops there. It is this African connection which has resulted in the Germans' reluctance to deploy the Battlegroups.

What is interesting, however, is that the Poles' similar view concerning where force is used, which is based on the country's regional threat perceptions, has not restricted the country's activism further afield. Thus, what might have appeared to be a similarity between German and Polish strategic cultures has turned out not to be the case. This is due to the relative strength in the Germans' restrictions on the use of force in comparison to the relative weakness of Poland's regional view when it comes into conflict with other aspects of its strategic culture. In particular this concerns 'nothing about us without us' in which Poland should be involved in decisions affecting the country's interests and the importance the Poles' place on being a reliable ally. This has led to Polish policy-makers increasing willingness to participate in CSDP and the desire to hold a leadership role. In this respect the Battlegroups have enabled this to take place in addition to acting as a catalyst for military development. 
Evidently, there has been some convergence between German and Polish strategic cultures. This encompasses the Germans' increased activism in using force out of area and the broadening of Polish security interests combined with an agreement that the EU should be an independent security actor, particularly in the civil-military field, as long as it does not duplicate NATO. More specifically to the Battlegroup Concept, the atlanticist-europeanist dimension does not come into play due to the rapid reaction nature of the Battlegroups.

However this does not result in a fully fledged strategic culture which would offer a framework concerning the EU's use of military force and thus provide a foundation for the use of the Battlegroups. Therefore whether a Battlegroup is deployed or not will depend on whether it is in each participating member states' interest to do so. In this respect whilst the Battlegroups were created to provide additional usable rapid reaction capabilities and to avoid the need for ad hoc force generation processes, they have not overcome the political willingness hurdles. Consequently, the continued failure of the EU's member states to agree on precisely when, where and how the EU uses force could not only spell the end of the Battlegroup Concept but could also undermine the EU's international reputation as a security provider.

\section{$\underline{\text { References }}$}

$138^{\text {th }}$ Bergedorf Round Table, 2007. Can the EU Ensure Europe's Security?, Hamburg: Körber-Stiftung.

Agence Europe, 2009. The Day in Politics, 30 September.

Alecu de Flers, N, Chappell, L and Müller, P, 2011 (Forthcoming). The EU's Foreign and Security Policy: Incremental Upgrading of Common Interests and the Effects of 
Institutionalised Cooperation. In $\mathrm{G}$ Falkner ed. The EU's Decision Traps: Comparing Policies, Oxford: Oxford University Press.

Andersson, J.J. 2006, Armed and Ready: the EU Battlegroup Concept and the Nordic Battlegroup. Report No. 2, Stockholm: Swedish Institute for European Policy Studies.

Baltic News Service, 2006. Lithuania, 4 More Countries to Form Joint Battle Group, Vilnius, November 13.

Baun, M, 2005. How Necessary is a Common Strategic Culture? In: A, Toje ed. A Strategic Culture for Europe. EU Security Policy after Iraq, Oxford Journal on Good Governance, 2 (1), 33-38.

Chappell, L, 2009. Deploying the EU Battlegroups: Mission Impossible?, CFSP Forum, 7 (6), 7-12.

Council of the European Union, The European Union Battlegroups, Brussels, January 2007. Council of the European Union, EU Battle Groups Offers and Commitments (EU BG Roster), 14337/05, Brussels, 11 November 2005.

Council of the European Union, 2582 ${ }^{\text {nd }}$ Council Meeting General Affairs and External Relations, Brussels, 17 May 2004, 9210/04, Available from: http://www.consilium.europa.eu/ueDocs/cms_Data/docs/pressdata/en/gena/80498.pdf [Accessed 18 March 2007]. 
Czech News Agency, 2009, EU Battlegroups to be Deployed in Disasters - French General, Prague, 22 January.

Duffield, J.S, 1998. World Power Forsaken, Stanford: Stanford University Press.

Duffield, J.S, 1994. German Security Policy after Unification: Sources of Continuity and Restraint, Contemporary Security Policy, 15 (3), 170-198.

European Council, EU-UN Co-operation in Military Crisis Management Operations Elements of Implementation of the EU-UN Joint Declaration, Brussels, 17-18 June 2004. Available from: http://www.consilium.europa.eu/uedocs/cmsUpload/EU-UN\%20cooperation\%20in\%20Military\%20Crisis\%20Management\%20Operations.pdf [Accessed 20 February 2007].

European Defence Agency. Declaration of Intent Regarding the Establishment of a European Air Transport Fleet, Brussels, 10 November 2008.

EU Council Secretariat. Factsheet - Financing CSDP Operations. Brussels, EU Council Secretariat, June 2006. Available from: http://www.consilium.europa.eu/uedocs/cmsUpload/Factsheet_Financing2.pdf [Accessed 31 January 2007].

European Union Military Committee. BG Update and the EUMC Report to PSC on the Outcome of BGCC 1/09, 9244/09 Ext 1, Brussels, 29 April 2009. 
European Union Military Committee. BG Update and the EUMC Report to PSC on the Outcome of BGCC 2/08, 14833/08 Ext 1, Brussels, 28 October 2008.

France, Germany, UK. Capabilities Development in Support of EU Rapid Response 'The Battlegroup Concept' FR/DE/UK Food for Thought Paper. 10 February 2004. Available from: http://www.geopowers.com/Allianzen/EU/akt_eu/RRF_BGConcept.pdf [Accessed $16^{\text {th }}$ June 2006].

Gągor, F, 2007. Our Achievements, Our Challenges, Military Technology, 08/2007. Available from: http://www.sgwp.wp.mil.pl/strona.php?idstrona=34 [Accessed 3 February 2009].

Gernot, E, 2007. Political principles of the German engagement in international peace missions. Speech by Minister of State Erler at the United Nations in New York, 6 February.

Cornish, P and Edwards, G, 2005. The Strategic Culture of the European Union: a Progress Report. International Affairs, 81 (4), 801-820.

Gowan, R, 2005. The Battlegroups: A Concept in Search of a Strategy? In S. Biscop, ed. E Pluribus Unum? Military Integration in the European Union, Egmont Paper 7, Royal Institute for International Relations (IRRI-KIIB), Brussels: Academia Press.

Granholm, N. 2006. EU-Battlegroups Some New Capabilities, Actually. RUSI Journal, 151 (6), 62-66. 
Gray, C.S, 1999. Strategic Culture as Context: The First Generation of Theory Strikes Back. International Affairs, 7 (1), 49-69.

Gross, E, 2009. The Europeanization of National Foreign Policy: Continuity and Change in European Crisis Management, Basingstoke: Palgrave Macmillan.

Heiselberg, S, 2003, Pacifism or Activism: Towards a Common Strategic Culture Within the European Security and Defense Policy?. ISS Working Paper, no. 2, Copenhagen: Danish Institute for International Studies. Available from: http://www.dupi.dk/webdocs/w0403.pdf [Accessed 23rd March 2006], 1-36.

Jacoby, W and Jones, C, 2008. The EU Battle Groups in Sweden and the Czech Republic: What National Defense Reforms Tell Us about European Rapid Reaction Capabilities. European Security, 17 (2), 315-338.

Johnston, A.I, 1995. Cultural Realism: Strategic Culture and Grand Strategy in Ming China, Alas-Princeton, N.J; Chichester: Princeton University Press.

Kawałowski, M, 2007. Grupy bojowe Unii Europejskiej, Kwartalnik Bellona ${ }_{2}$ I/2007, 46-54.

Kerttunen, M, 2005. The Concept. In M. Kerttunen, T. Koivula, and T. Jeppsson, eds. EU Battlegroup-Theory and Development in the Light of Finnish-Swedish Co-operation. Series 2, Research Reports No. 30, Helsinki: Department of Strategic and Defence Studies, National Defence College. Available from: 
http://www.mpkk.fi/attachment/ad9d29e3539815313b364464a41b98a9/0379a258c9db18b78 86e8066a0a5bb2a/EU+Battlegroups [Accessed 12 June 2006].

Koivula, T, 2005. EU Battlegroup: The Big Picture, In M. Kerttunen, T. Koivula, and T. Jeppsson, eds. EU Battlegroup-Theory and Development in the Light of Finnish-Swedish Co-operation. Series 2, Research Reports No. 30, Helsinki: Department of Strategic and Defence Studies, National Defence College. Available from: http://www.mpkk.fi/attachment/ad9d29e3539815313b364464a41b98a9/0379a258c9db18b78 86e8066a0a5bb2a/EU+Battlegroups [Accessed 12 June 2006].

Komorowski, S.J, Poland's Objectives in European Security \& Defence, Paper presented at the $7^{\text {th }}$ Congress on European Security and Defence, Berlin, November 2008. Available from: http://www.european-defence.com/ [Accessed 3 February 2009].

Lindstrom, G, 2007. Enter the EU Battlegroups. Chaillot Paper, 97, Paris: Institute for Security Studies.

Longhurst, K, 2004. Germany and the Use of Force, Manchester: Manchester University Press.

Longhurst, K and Zaborowski, M, 2003. America's protégé in the east? The emergence of Poland as a regional leader. International Affairs, 79 (5), 1009-1028.

Meller, S. Government information on Polish foreign policy in 2006, Sejm, Warsaw, 15 February 2006. 
Memorandum of Understanding between the Federal Ministry of Defence of the Federal Republic of Germany and the Ministry of Defence of the Republic of Latvia and the Ministry of National Defence of the Republic of Lithuania and the Minister of National Defence of the Republic of Poland and the Ministry of Defence of the Slovak Republic Concerning the Framework Regulations for the European Union Battlegroup (EU BG 2010), Brussels, 13 November 2006.

Menon, A. 2009. Empowering Paradise? The CSDP at Ten. International Affairs, 85 (2), 227-246.

Meyer, C.O, 2006. The Quest for A European Strategic Culture: Changing Norms on Security and Defence in the European Union, New York: Palgrave Macmillan.

Ministry of Foreign Affairs of the Republic of Latvia. Foreign Minister signs memorandum of understanding on creation of a joint EU Battlegroup, 14 November 2006. Available from: http://www.mfa.gov.lv/en/security/news/4457/?pg=8433 [Accessed 3 March 2007].

NATO. SAC flies its first humanitarian relief flight to Haiti, 16 January 2010. Available from: http://www.nato.int/cps/en/natolive/news_60782.htm?selectedLocale=en [Accessed 30 March 2010].

Neesen, N, 2005. Das Einsatzfuehrungskommando der Bundeswehr als strategisches Hauptquartier der EU, Europäische Sicherheit, Vol. 11, 36-41. 
Osica, O, 2004a. Poland: A New European Atlanticist at a Crossroads?. European Security, 13 (4), 301-322.

Osica, O, 2004b. A Secure Poland in a Better Union? The ESS as Seen from Warsaw's Perspective, In Overhaus, M, Maull, H. W, Harnisch, S, The European Security Strategy Paper Tiger or Catalyst for Joint Action? - Part II Perspectives from Italy, Poland, Austria and Finland. German Foreign Policy in Dialogue, Newsletter 5 (14), [Online], http://www.deutsche-aussenpolitik.de/newsletter/issue14.pdf, [Accessed 25th January 2007], 9-15.

Reis, B.C, 2009. Europeans are from Athens: European Strategic Culture and the deepening of ESDP in an Enlarged EU. EU Consent Project -No. 513416. Paper based on discussed held at the Lisbon conference on New Perspectives for European Security, by Team 24.

Rogers, J, 2009. From 'Civilian Power' to 'Global Power': Explicating the European Union's 'Grand Strategy' Through the Articulation of Discourse Theory, Journal of Common Market Studies, 47 (4), 831-862.

Rotfeld, A, Information of the Government of the Republic of Poland on the Polish Foreign Policy in the Year 2005, delivered by the Minister of Foreign Affairs Adam Daniel Rotfeld, Sejm, Warsaw, 21 January 2005.

Ryjáceek, J, 2009. Losing the Power of Parliament? Participation of the Bundestag in the Decision-Making Process Concerning Out-of-Area Military Operations. German Politics, 18 (4), 485-500. 
Rynning, S, 2003. The European Union: Towards a Strategic Culture?, Security Dialogue, 34 (4), $479-496$

Solana, J, 2008. Report on the Implementation of the European Security Strategy - Providing Security in a Changing World, Brussels: Council of the European Union.

Spiegel Online, 2009, Airbus Faces A400M Order Cancellations Due to Delays, 2 March Available from: http://www.spiegel.de/international/europe/0,1518,610732,00.html [Accessed 2 March 2009].

Terlikowski, Marcin, 2010. Polish-led EU Battle Group, PISM Bulletin, No. 3 (79), January 11.

Toje, A (ed.), 2005. A Strategic Culture for Europe. EU Security Policy after Iraq, Oxford Journal on Good Governance, 2 (1).

The Ministry of National Defence of the Republic of Poland. CREVAL - ready to operate, Warsaw, 11 December 2008. Available from: http://www.mon.gov.pl/en/artykul/6268 [Accessed 20 January 2009].

The Warsaw Voice, 2006. EU Battle Group, 24 November.

Wendt, A, 1999. Social Theory of International Politics, Cambridge: Cambridge University Press. 
Williams, T, 2006. Whose finger will be on the EU Battlegroups' trigger? Europe's World, 46-51.

Witney, N, 2008. Re-Energising Europe's Security and Defence Policy, London: European Council on Foreign Relations.

Table 1 - EU Battlegroup Commitment Roster from 2005-2015 ${ }^{17}$

\begin{tabular}{|c|c|c|}
\hline Standby Period & Contributing member states & Point of Contact ${ }^{18}$ \\
\hline \multicolumn{3}{|l|}{ Previous Battlegroups } \\
\hline $2005 / \mathrm{I}$ & 1. UK & 1. UK \\
\hline & 2. France & 2. France \\
\hline 2005/II & 1. Italy & 1. Italy \\
\hline 2006/I & $\begin{array}{l}\text { 1. Germany, France } \\
\text { 2.Spain, Italy, Portugal, Greece }\end{array}$ & $\begin{array}{l}\text { 1. Germany } \\
\text { 2. Spain }\end{array}$ \\
\hline 2006/II & 1. France, Germany, Belgium & 1. France \\
\hline $2007 / \mathrm{I}$ & $\begin{array}{l}\text { 1. Germany, Netherlands, Finland } \\
\text { 2. France, Belgium }\end{array}$ & $\begin{array}{l}\text { 1. Germany } \\
\text { 2. France }\end{array}$ \\
\hline $2007 / \mathrm{II}$ & $\begin{array}{l}\text { 1. Italy, Hungary, Slovenia } \\
\text { 2. Greece, Cyprus, Romania, Bulgaria }\end{array}$ & $\begin{array}{l}\text { 1. Italy } \\
\text { 2. Greece }\end{array}$ \\
\hline $2008 / \mathrm{I}$ & $\begin{array}{l}\text { 1. Sweden, Finland, Estonia, Norway, Ireland } \\
\text { 2. Spain, France, Germany }\end{array}$ & $\begin{array}{l}\text { 1. Sweden } \\
\text { 2. Spain }\end{array}$ \\
\hline 2008/II & $\begin{array}{l}\text { 1. Germany, France, Spain, Belgium, } \\
\text { Luxembourg } \\
\text { 2. UK }\end{array}$ & $\begin{array}{l}\text { 1. Germany } \\
\text { 2. UK }\end{array}$ \\
\hline $2009 / \mathrm{I}$ & $\begin{array}{l}\text { 1. Italy, Spain, Portugal, Greece } \\
\text { 2. Greece, Bulgaria, Cyprus, Romania }\end{array}$ & $\begin{array}{l}\text { 1. Italy } \\
\text { 2. Greece }\end{array}$ \\
\hline 2009/II & $\begin{array}{l}\text { 1. Czech Republic, Slovakia } \\
\text { 2. Belgium, France, Luxembourg }\end{array}$ & $\begin{array}{l}\text { 1. Czech Republic } \\
\text { 2. Belgium }\end{array}$ \\
\hline \multicolumn{3}{|l|}{ Current Battlegroups } \\
\hline 2010/I & $\begin{array}{l}\text { 1. Poland, Germany, Latvia, Lithuania, Slovakia } \\
\text { 2. UK, Netherlands }\end{array}$ & $\begin{array}{l}\text { 1. Poland } \\
\text { 2. UK }\end{array}$ \\
\hline \multicolumn{3}{|l|}{$\begin{array}{l}\text { Future Battlegroups - } \\
\text { Firm Commitments }\end{array}$} \\
\hline 2010/II & $\begin{array}{l}\text { 1. Italy, Romania, Turkey } \\
\text { 2 Spain, France, Portugal }\end{array}$ & $\begin{array}{l}\text { 1. Italy } \\
\text { 2. Spain }\end{array}$ \\
\hline $2011 / \mathrm{I}$ & $\begin{array}{l}\text { 1. Netherlands, Germany, Finland, Austria, } \\
\text { Lithuania } \\
\text { 2. Sweden, Finland, Norway, Estonia and Ireland }\end{array}$ & $\begin{array}{l}\text { 1. Netherlands } \\
\text { 2. Sweden }\end{array}$ \\
\hline \multicolumn{3}{|l|}{$\begin{array}{l}\text { Future Battlegroups - } \\
\text { Commitments }\end{array}$} \\
\hline 2011/II & $\begin{array}{l}\text { 1. Greece, Bulgaria, Cyprus, Romania } \\
\text { 2.Portugal, Spain, France, Italy }\end{array}$ & $\begin{array}{l}\text { 1. Greece } \\
\text { 2. France or Portugal }\end{array}$ \\
\hline $2012 / \mathrm{I}$ & $\begin{array}{l}\text { 1. France, Belgium Luxembourg } \\
\text { 2. Vacant }\end{array}$ & 1. France \\
\hline 2012/II & 1. Italy, Slovenia, Hungary & 1. Italy \\
\hline
\end{tabular}




\begin{tabular}{|l|l|l|}
\hline & $\begin{array}{l}\text { 2. Germany, Austria, Czech Republic, Croatia, } \\
\text { FYR Macedonia and possibly Ireland }\end{array}$ & 2. Germany \\
\hline $2013 / \mathrm{I}$ & $\begin{array}{l}\text { 1. Poland, Germany, France } \\
\text { 2. Vacant }\end{array}$ & 1. Poland \\
\hline $\begin{array}{l}\text { Future Battlegroups }- \\
\text { Initial Offers }\end{array}$ & & \\
\hline $2013 / \mathrm{II}$ & $\begin{array}{l}\text { 1. UK, Sweden } \\
\text { 2. Belgium, Luxembourg tbc - possibly France }\end{array}$ & $\begin{array}{l}\text { 1. UK } \\
\text { 2. Belgium }\end{array}$ \\
\hline $2014 / \mathrm{I}$ & $\begin{array}{l}\text { 1. Greece and tbc. Bulgaria, Romania and Cyprus } \\
\text { 2. Vacant }\end{array}$ & \begin{tabular}{l} 
1. Greece (tbc) \\
\hline 2015
\end{tabular} \\
$\begin{array}{l}\text { Poland, Czech Republic, Slovakia, Hungary and } \\
\text { possibly Ukraine }\end{array}$ & \\
\hline
\end{tabular}

${ }^{1}$ Confidential interview conducted by the author with a German civil servant, Berlin, 2007

${ }^{2}$ Confidential interview conducted by the author with a Polish civil servant, Warsaw, 2007

${ }^{3}$ Confidential interviews conducted by the author with Polish civil servants in Brussels and Warsaw, 2006 and 2007

${ }^{4}$ Confidential interview conducted by the author with a German civil servant, Berlin, 2006.

${ }^{5}$ Confidential interviews conducted by the author with a researcher and a former high ranking civil servant, Berlin, 2006

${ }^{6}$ Confidential interview conducted by the author with a researcher and former civil servant, Berlin, 2006

${ }^{7}$ Confidential interviews conducted with German party officials, Berlin, 2007.

${ }^{8}$ Confidential interview conducted by the author with a researcher, Warsaw, 2007

${ }^{9}$ Along with the 60 planes that Germany has ordered, France has ordered 50, Spain 27, the UK 25, Turkey 10 and Belgium 8 - one of which is on behalf of Luxembourg.

${ }^{10}$ Participating countries include Bulgaria, Estonia, Hungary, Lithuania, the Netherlands, Norway, Poland, Romania, Slovenia and the US as well as two non-NATO members - Finland and Sweden.

${ }^{11}$ Confidential interview conducted by the author with a Polish civil servant, Warsaw, 2007

12 The original states 'będzie wart rozważenia w przyszłości, w miarę postępowania procesu transformacji Sił Zbrojnych RP, implementacji wniosków strategicznego przeglądu obronnego oraz doświadczeń operacyjnych (Irak, Afganistan, DR Konga). 
${ }^{13}$ Confidential interview conducted by the author with Polish civil servants, Warsaw, 2007.

${ }^{14}$ Confidential interview conducted by the author with a German civil servant, Berlin, 2007

${ }^{15}$ Confidential interviews conducted by the author with an official in the Council of the European Union, Brussels 2007 and a researcher, Warsaw, 2007.

${ }^{16}$ In the original it reads 'Pobudza też rozwój i modernizację naszych sił zbrojnych'.

${ }^{17}$ The information used to compile this table was taken from Niklas Granholm, Niklas, 'EU-Battlegroups Some New Capabilities, Actually', RUSI Journal, 151/6, (2006), p66; Nico Neesen, 'Das Einsatzfuehrungskommando der Bundeswehr als strategisches Hauptquartier der EU’, Europaeische Sicherheit, Vol. 11, 2005, p39; Council of the European Union, EU Battle Groups Offers and Commitments (EU BG Roster), 14337/05, 11 November 2005, Brussels, p2; Gustav Lindstrom, Gustav, Enter the EU Battlegroups, p88; The Irish Times, Government weighs up transferring to new EU Battlegroup, 28 July 2008; European Union Military Committee, BG Update and the EUMC Report to PSC on the Outcome of BGCC 2/08, Brussels, 28 October 2008, 14833/08 Ext 1, p3 and European Union Military Committee, BG Update and the EUMC Report to PSC on the Outcome of BGCC 1/09, Brussels, 29 April 2009, 9244/09 Ext 1, p3.

${ }^{18}$ The point of contact does not have to correspond to the Framework Nation for each Battlegroup, although in most cases it does. 